TAPROBANICA, ISSN 1800-427X. April, 2009. Vol. 01, No. 01: pp. 28-35.

(C) Taprobanica Nature Conservation Society, 146, Kendalanda, Homagama, Sri Lanka.

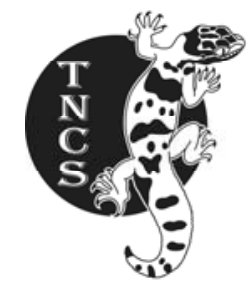

\title{
THE AVIFAUNA OF SRI LANKA: AN OVERVIEW OF THE CURRENT STATUS
}

Submitted: 19 February 2009, Accepted: 31 March 2009

\author{
Deepal Warakagoda ${ }^{1}$ and Udaya Sirivardana ${ }^{1,2}$ \\ ${ }^{1}$ Ceylon Bird Club, 127, Nawala Rd, Colombo 5, Sri Lanka \\ ${ }^{2}$ Corresponding author: birdclub@sltnet.lk
}

\begin{abstract}
Sri Lanka has a high diversity of avifauna, with 236 breeding and 203 purely migrant species. Among the former, 33 species and a further 68 subspecies are endemic to it. Since the systematic study of the birds of the island began in the 18th century intermittent discoveries of breeding and migrant taxa have led to a gradual increase in the total number of taxa known to occur in it. Different taxonomic treatment over time has resulted in the number of endemic species recognised varying from 47 in 1880 to 21 in 1978 and 33 in 2005. The present enumeration of species in the avifaunal list for Sri Lanka is based on the work of the Ceylon Bird Club Rarities and Records Committee, as embodied in Henry (1998) and relative to standard ornithological publications for the region. An authentic list for a country reflects the true diversity of the avifauna within it and contributes to the mapping of correct global distribution especially of widespread or migrating taxa. 46 species of birds in Sri Lanka, including 16 endemic to it, are recognised as Threatened.
\end{abstract}

Key words: Birds, country list, endemic, Threatened, breeding species, migrant species

\section{Avifaunal diversity in Sri Lanka}

Sri Lanka is a large continental land-bridge island, located both in the tropical belt and in the South Asia region. The latter is recognised today as a significant avifaunal entity (Rasmussen \& Anderton, 2005). The geographic position and topography of Sri Lanka has given the island three major climatic zones and a wide variety of habitats within each. These zones and habitats support an avifauna of high species diversity.

The majority of these species are breeding residents. Originally from a common landmass shared with India, many have evolved in to distinct forms within the island's substantial montane massifs which have 